\title{
Bank Recapitalization and Real Sector Performance: Empirical Evidence From Nigeria.
}

\author{
Ebenezer Y. Akinkoye, $\mathrm{PhD}^{\mathrm{a}}$, Lukman .O. Oyelami ${ }^{\mathrm{b}}$ \\ ${ }^{a}$ Obafemi Awolowo University, Ile-ife Osun State. Nigeria \\ ${ }^{b}$ Distance Learning Institute (Economics Unit) University of Lagos, Akoka, Lagos. 100213, Nigeria
}

\begin{abstract}
This study investigates the impact of bank recapitalization on real sector performance in Nigeria. Specifically, the study examines the direct effect (bank investment) and indirect effect (loans and advances to real sector) on real sector output growth between the period 1986 and 2012.This study departs from previous studies because we aggregate the three leading sectors (agriculture, manufacturing and building and construction) of the Nigerian economy to arrive at our real sector index. Also, having carefully subjected our data to necessary econometric tests we employed chow test for structural break to test for the existence of policy shift between bank capital base and loan to the real sector of the Nigerian economy as a result of bank recapitalisation policy. Similarly, OLS estimates was used to determine the direct and indirect effect of bank capital base and real sector output growth. The results from structure break tests reveal that bank recapitalization policy causes policy shift in bank capital base and loan to real sector thus the policy is of significant impact to real sector performance. In corollary, the result from the OLS strongly indicates that bank capital base has significant effect on real sector output growth directly and indirectly. We then conclude that Nigerian banks should be adequately capitalised as to play active intermediateting roles expected of them in this modern and competitive global economy.
\end{abstract}

Key Words: Recapitalization, Economics, Growth, and Bank

JEL: $E 22$;O49; G28

\section{(C) 2014 Published by SSBFNET}

\section{Introduction}

Financial liberation has created opportunity for increasing integration of world's financial system and also posed a serious challenge for the developing countries of the world due to their fragile financial system which make them vulnerable to external financial shocks. This always inhibits such financial system from playing critical roles required in modern economy. In recognition of this problem, an international agreement among the banking authorities known as Basle agreement was reached in 1988. The main objective of this international agreement was to apply a common

\footnotetext{
${ }^{i}$ Corresponding author
} 
set of rules for capital adequacy in order to minimize the risk of bank failures. Consequently, several countries especially developing countries have carried out banking reforms in attempt to improve the efficiency and effectiveness of the entire banking system and bring improvement in the quality of financial system.

In Nigeria, several banking reforms have been undertaken but bank recapitalization has received greater attention and been adjudged to be the main driving force of bank reforms in the country Omoruyi (1991). This seems to be justifiable as other scholars have emphasised the importance of adequate capitalisation in the banking industry. For instance, Spong (1990) commercial bank must have enough capital to provide a cushion for absorbing possible loan losses, funds for its internal needs, expansion and added security for depositors.Also, Boyd and Runkle. (1993), Demirguc-kunt and Levine (2003), Sulaiman (2004) and Imala (2005) corroborate this assertion. In recognition of the potential benefit derivable from this, series of bank recapitalisation policy has been implemented in Nigeria starting from 1952 to the most recent one in year 2005.

Empirically, serious effort has been invested in unravelling the link between bank capitalization and bank performance in the country without a concrete consensus. While this controversy still lingers, little or no attention has been given to how bank recapitalization impacts on the economy in general and real sector of the Nigerian economy in particular. Since banks and entire financial system majorly exist to serve other sectors of the economy through their intermediation activities, thus it should be of empirical desirability to measure their performance in this regard and this necessitate the study of this nature in a small open economy like Nigeria. Apart from this introductory section which is section one; the study is principally sectionalised into four components. Section two discusses the stylized fact banks and their capital base with reference to Nigeria while section two examined the extant literature of the subject matter. This is followed by section four and five which capture the methodology employed in the study and the conclusion generated therein.

\section{Stylized Fact about the Bank Capital Base and Real Sector Activities in Nigeria}

The table one shows the required minimum paid- up capital of both commercial and merchant bank between 1952 and 2005. From the table, it is clear that Nigerian banking industry has witnessed series of recapitalization policy especially after 1988 Basle agreement. This is an indication that Nigeria responded aptly to the problem of inadequate capital base of banks raised at the conference.

According to Central Bank of Nigeria (CBN), outcome of the last capitalization exercise revealed that twenty-five banks emerged from 75 banks, out of a total of 89 banks that existed as at June 2004 and the successful banks account for about $93.5 \%$ of the deposit liabilities of the banking system. In the process of complying with the minimum capital requirement, N406.4 billion was raised by banks from the capital market and the process led to the inflow of FDI of US\$652 million and 162,000 pounds sterling. Also, the process engendered the inflow of funds into the banks thus induced interest rate to fall drastically which provided an unprecedented $40 \%$ increase in lending to the real sector. CBN reports. 
Table 1. Minimum paid-up capital banks in Nigeria (1952 - 2005).

\begin{tabular}{llc}
\hline Year & Type of bank & Minimum account $(£)$ \\
\hline 1952 & Commercial Banks & $12,500.00$ \\
1969 & Commercial Banks & $300,000.00$ \\
& & $(\mathrm{AH})$ \\
1979 & Commercial Banks & $600,000.00$ \\
& Merchant Banks & $2,000,000.00$ \\
1988 (February) & Commercial Banks & $5,000,000.00$ \\
& Merchant Banks & $3,000,000.00$ \\
1988 (October) & Commercial Banks & $10,000,000.00$ \\
& Merchant Banks & $6,000,000.00$ \\
1989 & Commercial Banks & $20,000,000.00$ \\
& Merchant Banks & $12,000,000.00$ \\
1991 & Commercial Banks & $50,000,000.00$ \\
& Merchant Banks & $40,000,000.00$ \\
1997 & Commercial Banks & $500,000,000.00$ \\
& Merchant Banks & $500,000,000.00$ \\
2000 & Commercial Banks & $1,000,000,000.00$ \\
& Merchant Banks & $1,000,000,000.00$ \\
2001 & Commercial Banks & $2,000,000,000.00$ \\
& Merchant Banks & $2,000,000,000.00$ \\
& & $25,000,000,000.00$ \\
\hline
\end{tabular}

Source: Admimorah, C. I. (1988); FBN Business Report, June 2005.

In an attempt to see the response of the real sector of the economy to bank capital adequacy directly and indirectly, we show in figure one the co-movement of bank capital base, loan to real sector and real sector output between 1986 and 2012. The values in the figure are presented in log form and it shows that there is upward trend in both bank capital base and loans to the real sector thus suggesting an indirect effect. Also, it is depicted from the figure that real sector barely respond to movement in both bank capital base and loans issued to the sector. 


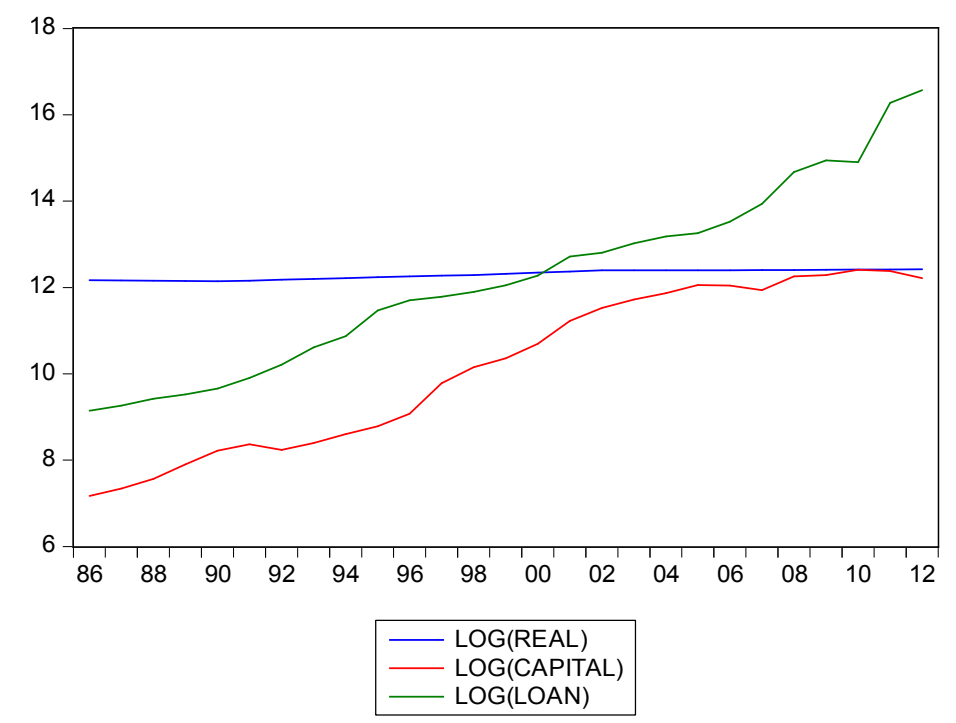

Figure 1: Trends Real Capital and Loan.

\section{Literature Review.}

The bulk of existing literature on this topic gives major attention to financial sector development and economic growth on one hand and bank performance and economic growth on the other hand. Also, since financial system in many developing countries including Nigeria is principally dominated by the activities of banks it is relevant to consider recapitalization of banks as a step towards improving financial sector development and this form the core of this literature.

The link between financial sector development and economic growth has always been controversial in economic literature. According to Schumpeter (1934) financial institutions provide efficient means of mobilizing and allocating funds in the economy and hence assist in the economic development process. However, he did not perceive the financial sector development as being the cause of economic development. Similarly, Robinson (1954) in his study referred to the financial sector as the handmaiden of economic development.

The implication of this is that financial sector is a passive sector that only responds to the needs of the real sector. However the works of McKinnon (1973) and Shaw (1973) came up with the argument that the financial sector can be more than a handmaiden to the real economy, and that it can serve as the major driver of economic growth and development if it can only be relieved of its own fetters. They argued that when a financial sector is repressed then it can only respond passively to the real-sector needs and if the sector is liberalized however, it can be the major drive for economic growth. Williams and Mahar (1998) also arguing along this lines and maintain that if the financial sector is free it can provide the necessary impetus for economic growth and development. Levine et al (2000) also confirmed that as the components of financial intermediation grow there seems to be positive growth in the real sector. The causal direction was however not established. 
Similarly, in Nigeria Adegbite (2004) using the ratio of broad money supply $\left(\mathrm{M}_{2}\right)$ to GDP as a measure of financial sector growth and deepening, found a positive correlation between financial sector growth and real sector growth. In a specific manner, the study by Bakare (2011) argues that bank recapitalisation has significant impact on the economy though the study also fails to establish causality between the two variables. In a somewhat contrary manner, study by Somoye (2008) posits that consolidation (recapitalisation) of banks may not necessarily be a sufficient tool for financial stability thus it might not propel economic growth as expected.

Also, at the theoretical level the proponents of bank recapitalization believe that increased capital base has potential to increase bank returns through revenue and cost efficiency gains. To the contrary, the critics argued that recapitalization has increased bank's propensity toward risk taking through increases in leverage and off balance sheet operations. So far, the nexus among recapitalization policy, financial sector development and economic growth has been polarised theoretically and empirically.

\section{Methodology}

To determine the impact of bank recapitalization on real sector of the economy in Nigeria, we employed time series data on the capital base of all the commercial banks operating in Nigerian economy and the amount of loan and advances they have issued to the real sector of the economy. Also, in determining the performance of the real sector of the economy, we aggregate the real GDP in three different sectors: Agricultural sector, Manufacturing and Mining and Building and construction. This is an attempt to narrow our focus to specific sectors of the economy and avoid the weakness of the past studies whereby real sector is proxied by real GDP of the whole economy.

\subsection{Descriptive Statistic of the data}

Table two presents the descriptive statistical properties of the data employed in the study: Capital base, loan and real sector output. The results show that the mean of the series is generally smaller than the standard deviation. Also, Jarque-Bera statistics show that two of the series are normally distributed as the probability is significant at $1 \%$ and 5 $\%$ significant level for loan and output respectively. To the contrary, the results reveal that the capital base variable is not normally distributed as Jarque-Bera statistic is not significant at 5\% and $10 \%$ significant level. 
Table 2: Descriptive Statistical Properties

\begin{tabular}{|l|l|l|l|}
\hline & CAPIT & LOAN & OUTPUT \\
\hline & & & \\
\hline Mean & 70916.02 & 541695.3 & 5484083. \\
\hline Median & 25634.80 & 146761.6 & 2188237. \\
\hline Maximum & 245159.9 & 3240579. & 21108013 \\
\hline Minimum & 1298.700 & 9353.900 & 46200.32 \\
\hline Std. Dev. & 82445.71 & 895249.1 & 6656805. \\
\hline Skewness & 0.803566 & 2.060149 & 1.110639 \\
\hline Kurtosis & 2.133874 & 5.949985 & 2.816874 \\
\hline & & & \\
\hline Jarque-Bera & 3.471926 & 26.74924 & 5.174592 \\
\hline Probability & 0.176230 & 0.000002 & 0.075223 \\
\hline & & & \\
\hline Sum & 1772900. & 13542383 & $1.37 \mathrm{E}+08$ \\
\hline Sum Sq. Dev. & $1.63 \mathrm{E}+11$ & $1.92 \mathrm{E}+13$ & $1.06 \mathrm{E}+15$ \\
\hline & & & 25 \\
\hline Observations & 25 & 25 & \\
\hline
\end{tabular}

\subsection{Econometric Properties of the Data}

\section{$\underline{\text { Unit Root Results }}$}

In an effort to determine the econometric properties of our data, unit root was conducted on the three variables using Augumented Dickey Fuller (ADF) and Philip Peron (PP) unit root tests. The reason for inclusion of Philip Peron unit roots test is the ability of the test to produce consistent results in face of structural break which is not impossible in this instance. The results from the tests as shown in table two indicate that capital base is stationary at first difference i.e. I(1) while indicating that loan is stationary at level i.e. I(0). In the case of real output variable the two tests produced contradicting results, While (ADF) shows the variable is stationary at second difference i.e. I(2) (PP) show that it stationary at level i.e. I(0). We therefore followed that of (PP) because of strength of the tests.

Table 3. Unit Root Table

\begin{tabular}{|c|c|c|c|c|c|c|c|}
\hline \multirow[t]{2}{*}{ Variables } & \multicolumn{6}{|c|}{ Unit root test } & \multirow{3}{*}{$\begin{array}{l}\text { Likely degree of } \\
\text { integration }\end{array}$} \\
\hline & $\mathrm{ADF}$ & & & $\overline{P P}$ & & & \\
\hline $\begin{array}{l}\text { With intercept } \\
\text { only }\end{array}$ & Level & $1^{\text {st }}$ diff. & $2^{\text {nd }}$ diff. & Level & $1^{\text {st }}$ diff. & $\begin{array}{l}2^{\text {nd }} \\
\text { diff. }\end{array}$ & \\
\hline Capital & 1.905285 & $-4.369010^{*}$ & & $\begin{array}{l}2.32886 \\
1\end{array}$ & $\begin{array}{l}- \\
4.39434 \\
0 *\end{array}$ & & $1(1)$ \\
\hline Loan & $4.597138^{*}$ & - & & $\begin{array}{l}4.61525 \\
3 *\end{array}$ & - & & $1(0)$ \\
\hline Output & 0.047695 & -1.097327 & $-12.19175^{*}$ & $\begin{array}{l}4.23884 \\
0^{*}\end{array}$ & & & $1(2),(0)$ \\
\hline
\end{tabular}


The difference in the level of stationarity of our data and the fact that capital which is key variable is stationary at first difference necessitated the need for co-integration tests. Also, the tests will provide platform to test for the existence of long term relationship among our variables. For this purpose, we separate capital and loan because of the high correlation that exists between the two variables and carried out separate co-integration tests for two set of variables. The results as indicated in table three A and B show that co-integration exists between loan and real output on one hand and capital and real output on the other hand. Specifically, one co-integrating equation is indicated in the case of capital and real output and two co-integrating equations in the case of loan and real output and this suggests the existence of long term relationship in our variables.

Table 4(a): Unrestricted Cointegration Rank Test (Trace)

\begin{tabular}{|c|c|c|c|c|}
\hline \multicolumn{5}{|c|}{ Unrestricted Cointegration Rank Test (Trace) } \\
\hline $\begin{array}{l}\text { Hypothesized } \\
\text { No. of CE(s) }\end{array}$ & $\begin{array}{l}\text { Trace } \\
\text { Eigenvalue }\end{array}$ & $\begin{array}{l}0.05 \\
\text { Statistic Critical }\end{array}$ & Value & Prob.** \\
\hline $\begin{array}{l}\text { None * } \\
\text { At most } 1\end{array}$ & $\begin{array}{c}0.832061 \\
0.069488\end{array}$ & $\begin{array}{l}42.69201 \\
1.656458\end{array}$ & $\begin{array}{l}15.49471 \\
3.841466\end{array}$ & $\begin{array}{l}0.0000 \\
0.1981\end{array}$ \\
\hline \multicolumn{5}{|c|}{$\begin{array}{l}\text { Trace test indicates } 1 \text { cointegrating eqn(s) at the } 0.05 \text { level } \\
* \text { denotes rejection of the hypothesis at the } 0.05 \text { level } \\
* * \text { MacKinnon-Haug-Michelis (1999) p-values }\end{array}$} \\
\hline
\end{tabular}

Table 4(b): Unrestricted Cointegration Rank Test (Trace)

\section{Unrestricted Cointegration Rank Test (Trace)}

Hypothesized

No. of CE(s)

None *

At most 1 *
Trace 0.05

Eigenvalue

0.817180

0.291890
Statistic Critical Value

15.49471

3.841466
Prob.**

0.0000

0.0048

\section{Trace test indicates 2 cointegrating eqn(s) at the 0.05 level \\ * denotes rejection of the hypothesis at the 0.05 level \\ **MacKinnon-Haug-Michelis (1999) p-values \\ 4.3 Estimation of Equation}

To empirically determine the effect of bank recapitalization on real sector performance we estimate the following two equations and test for structural break to determine policy shift in the year 2005 when recapitalization policy was implemented and other years when other crucial policies believed to be implemented in the banking sector.

$Y_{i}=C_{i}+X_{i}+e_{i}$

$Y_{i}=L_{i}+X_{i *}+e_{i}$ 
In equation one, $Y_{i}$ stands for real sector output while $C_{i}$ represents the capital base of commercial banks in the economy and $e_{i}$ stands for the usual error terms. Similarly, in equation two $Y_{i}$ for real sector output while $L_{i}$ stands for loans and advances to the real sector of the economy and $e_{i *}$ stands for the error term. In both equation $X_{i}$ and $X_{i *}$ stands for controlled variables introduced into model.

\subsection{Estimation Results}

The results from our model estimation as contained in table four A\&B reveal that both capital base of commercial bank and loan and advances syndicated to the real sector of the economy have significant effect on real sector output. The capital base as used in the model captures the direct impact of commercial bank aggregate capital in the economy on real sector output while the loan and advances capture indirect impact of the commercial bank aggregate capital in the economy on real sector output. Thus, it is safe to conclude that capital base of bank have both direct and indirect impact on real sector output. Specifically, a billion increases in the capital base of commercial banks is capable of increasing real sector output by thirty nine billion and this might suggest the existence of direct effect. Similarly, a billion increases in loan and advance given to the real sector of the economy can increase the real sector output by 2.2 billion.

Table 5(a): Dependent Variable: D(OUTPUT)

Dependent Variable: D(OUTPUT)

\begin{tabular}{lllll}
\hline Variable & Coefficient & Std. Error & t-Statistic & Prob. \\
& & & & \\
D(CAPIT) & 39.48882 & 12.54321 & 3.148223 & 0.0047 \\
$\mathrm{C}$ & 476334.2 & 232897.8 & 2.045250 & 0.0530 \\
& & & \\
R-squared & 0.310589 & Mean dependent var & \\
Adjusted R-squared & 0.279252 & S.D. dependent var & \\
\hline
\end{tabular}

Table 5 (b): Dependent Variable: D(OUTPUT)

Dependent Variable: D(OUTPUT)

\begin{tabular}{lcccc}
\hline Variable & Coefficient & Std. Error & t-Statistic & Prob. \\
D(LOAN) & 2.292776 & 0.741100 & 3.093747 & 0.0053 \\
$\mathrm{C}$ & 568889.0 & 219915.1 & 2.586857 & 0.0168 \\
& & & \\
R-squared & 0.303164 & Mean dependent var & 877575.5 \\
Adjusted R-squared & 0.271490 & \multicolumn{2}{c}{ S.D. dependent var } & 1124847. \\
\hline
\end{tabular}




\section{Chow Breakpoint Test}

To empirically test the influence of bank recapitalization policy in year 2005 we carried out a structural break test to determine whether the implementation of the policy constitutes a fundamental policy shift between the commercial banks loans and real sector output growth. The results as shown in table four indicate that the null hypothesis of no structural break is rejected in year 2005 implying that recapitalization of CBN constitutes a major policy shift in the relationship between the amount commercial banks loans to real sector and real sector output growth. To cross check our results, we also carried out structural break test on the relationship between commercial banks loans and real sector output in year 1992 when there was introduction of universal banking and 2008 when there was world financial crisis. The results as reported in table four B and C indicate that the hypotheses of no structural break cannot be rejected thus there is no structural break in the two periods.

Table 6(a): Chow Breakpoint Test: 2005

Chow Breakpoint Test: 2005

Null Hypothesis: No breaks at specified breakpoints

Equation Sample: 19872012

F-statistic

Table 6(b): Chow Breakpoint Test: 1992

Chow Breakpoint Test: 1992

Null Hypothesis: No breaks at specified breakpoints

Equation Sample: 19872012

F-statistic

1.056300

Prob. F(2,20)

0.3664

Log likelihood ratio

2.409968

Prob. Chi-Square(2)

0.2997

Wald Statistic

Table 6(c): Chow Breakpoint Test: 2008

\begin{tabular}{|c|c|c|c|}
\hline \multicolumn{4}{|c|}{ Chow Breakpoint Test: 2008} \\
\hline \multicolumn{4}{|c|}{$\begin{array}{l}\text { Null Hypothesis: No breaks at specified breakpoints } \\
\text { Equation Sample: } 19872010\end{array}$} \\
\hline F-statistic & 0.554430 & Prob. $F(2,20)$ & 0.5830 \\
\hline Log likelihood ratio & 1.295054 & Prob. Chi-Square(2) & 0.5233 \\
\hline Wald Statistic & 1.108860 & Prob. Chi-Square(2) & 0.5744 \\
\hline
\end{tabular}




\section{Conclusion and Implications}

From the foregoing analysis, it can be concluded that bank capital base has a very important effect on the real sector output performance both directly and indirectly. Also, bank recapitalization policy can impact significantly on the relationship between the banks loans and real sector output growth, thus it is safe to conclude that bank recapitalization impact on the real sector output performance and this seems to be in line with similar studies by Somoye (2008) and Bakere (2011).

\section{References}

Adegbite E.O, (2005). Global Banking; braving the odds; Niger. Bank. J22-25

Bakare.A.S, (2011).The Trend and Growth Implications of Bank recapitalization in Nigeria. African Journal of Business Management Vol. 5(14), 5938-5945.

Boyd JH, Runkle DE (1993). Size and Performance of Banking Firms:Testing the predictions of Theory. J. Monet. Econ., 31(7): 67-78

Demirguc-kunt A, Levine R (2000). Bank Concentrations Cross Country Evidence. McGraw-hills publishers, England.

Imala OI (2005). Challenges of Banking Sector Reforms and Bank Consolidation in Nigeria. CBN Bull., 4 (29):2-27

Levine, R. (1997). Financial Development and Economic Growth: Views and Agenda, Journal of Economic Literature, 35, 688-726.

Mckinnon, R. I. (1973). Money and Capital in Economic Development, Brookings Institution, Washington D.C.

Omoruyi SE (1991). The Financial Sector in Africa: Overview and Reforms in Economic Adjustment Programmes. CBN Econ. FinanRev., 29(4): 110-124.

Schumpeter, J. A. (1912). Theorie der Wirtschaftlichen Entwicklung. Leipzig: Dunker \& Humblot, The Theory of Economic Development: An Inquiry into Profits, Capital, Interest, and the Business Cycle, translated by Redvers Opie. Cambridge, MA: Harvard University Press, 1934].

Shaw, E. S. (1973). Financial Deepening in Economic Development, Oxford University Press, London and New York.

Soludo CC (2004). Consolidating the Nigerian Banking Industry to Meet the Development Challenges of the 21st Century. Bankers'Committee held on July 6, at the CBN Headquarter, Abuja

Somoye .R.O.C.(2008). The Performances of Commercial Banks in Post-Consolidation Period in Nigeria: An Empirical Review. European Journal of Economics, Finance and Administrative Sciences ISSN 1450-2275 Issue 14 (2008) 
Akinkoye \& Oyelami /International Journal of Finance \& Banking Studies Vol 3, No 1, 2014 ISSN: 2147-4486

Spong K (1990). Banking Regulations: Its Purposes, Implementation and Effects. Federal Reserve Bank of Kansas City, USA. 